Violetta Wejs-Milewska

Uniwersytet w Białymstoku

v.wejs.milewska@gmail.com

\title{
Między kreacją a świadectwem. Kilka uwag lekturowych na przykładzie poezji lagrowej Grażyny Chrostowskiej i Zofii Romanowiczowej
}

\author{
Between Creation and Testimony. A Few Reading Remarks on the Example \\ of Camp Poetry of Grażyna Chrostowska and Zofia Romanowiczowa
}

\begin{abstract}
Adopting the pars pro toto principle, the author of the article chose two concentration camp poets: Grażyna Chrostowska, who died at the age of 21, leaving behind a rather modest corpus of poems, and Zofia Romanowiczowa, who survived the war, moved to Paris and became a well-known, recognized and appreciated prose writer and columnist, who commented on the emigration life of Poles. Chrostowska was a very promising poet, whose talent had no possibility to develop, whereas Romanowiczowa was a fulfilled woman (wife and mother) and writer, who polished her writing style through the years and consciously built up her artistry. The question posed in the article is: To what extent does the prior knowledge of the two authors' biographies influence one's reception of their work? Does the aesthetic category, especially in the light of the authors' camp experiences, retain the primary character?
\end{abstract}

Keywords: women in the concentration camp, camp poetry, Grażyna Chrostowska, Zofia Romanowiczowa

Streszczenie: Autorka artykułu, przyjmując zasadę pars pro toto, wybrała dwie poetki lagrowe, z których jedna, Grażyna Chrostowska, zginęła w wieku 21 lat, pozostawiwszy po sobie dość skąpy korpus wierszy, druga - Zofia Romanowiczowa, przeżyła wojnę, zamieszkała w Paryżu i stała się znaną, rozpoznawalną oraz docenioną prozaiczką i publicystką, komentatorką emigracyjnego życia Polaków. Chrostowska była świetnie zapowiadającą się poetką, której los nie pozwolił rozwinać talentu, Romanowiczowa zaś - spełnionym człowiekiem (żoną, matka) i pisarką, która przez lata szlifowała swój styl i świadomie budowała artystyczny warsztat. Pytanie postawione w artykule brzmi: w jakim stopniu przedlekturowa wiedza o biografii autorek wpływa na recepcję twórczości? Czy kategoria estetyczna, zwłaszcza w kontekście traumatycznych przeżyć lagrowych obu autorek, zachowuje charakter prymarny?

Słowa kluczowe: kobiety w lagrze, poezja lagrowa, Grażyna Chrostowska, Zofia Romanowiczowa 


\section{Kreacja}

Pozwolę sobie rozpocząć mój szkic od poetyckiego cytatu - od przywołania treści wiersza młodej kobiety, Grażyny Chrostowskiej, utworu napisanego w 1942 roku w Ravensbrück. O okolicznościach powstania oraz zapisu Podróży (taki jest tytuł utworu) słowo później. Na marginesie dodam także, że enigmatyczna uwaga o autorce i jedynie wspomnienie o datowaniu wiersza, znajdzie swoje niezbędne dopełnienie w drugiej części wywodu. Chrostowska napisała:

Ucieknę chyłkiem późną nocą,

W daleki pomknę świat.

Gwiazdy się będą sypać w oczy,

Tysiące ślepych gwiazd.

O szczyty otrę się zuchwale,

Drzemiących we mgle gór,

I słuchać będę w srebrnej dali

Jak szumi, szumi bór.

W sennych jeziorach mrą widziadła

Popatrzę w głębię wód,

Przeniknę w ciemność, dojrzę na dnie,

$\mathrm{Na}$ piaskach niemy grób.

\section{Podróż $(1942)^{1}$}

Po zapoznaniu się z treścią utworu zadałam sobie pytanie fundamentalne z punktu widzenia zadania, jakie wybrzmiewa w tytule: czy zatem kontekst historyczny, pełna i przedlekturowa wiedza biograficzna o autorce wpływa (jeśli tak, to jak) na recepcję jej twórczości? Czy taki utwór ma wystarczającą wartość samoistną, autoteliczną, by zaistnieć jako interesujący kazus artystyczny, obronić się przed innymi, równie charakterystycznymi utworami, tworzonymi z myślą o wadze estetycznej kategorii? Czy może jednak sensy utworu pogłębia dopiero dramaturgia okoliczności powstania, każąca interpretatorowi dojrzeć w nim autentyczne świadectwo, które porusza i sprawia, że tekst przestaje być jednym z wielu?

Oczywiście, nie umiem interpretować tego utworu z pominięciem szczególnej okoliczności, jaka towarzyszyła procesowi twórczemu, gdyż wiem, kim była Grażyna Chrostowska, czym „zawiniła”, że karą był ostatecznie wyrok śmierci wykonany w lagrze, że straciła życie jako wciąż bardzo młoda kobieta (i dodajmy - bardzo piękna). Świadomie też używam kategorii „procesu

\footnotetext{
${ }^{1}$ G. Chrostowska, Wiersze, oprac. B. Oratowska, J. Cymerman, Lublin 2017, s. 80.
} 
twórczego"; ten wiersz bowiem dla samodzielnego istnienia jako osobny utwór artystyczny, byt umocowany w kulturze i w kontekście literackim, moim zdaniem nie potrzebuje autorskiej legendy, ale bez niej z pewnością byłby może znany tylko nielicznej, bardzo wąskiej grupie czytelników². Zwróćmy również uwagę na jego formalne i estetyczne rozwiązania, na to, że zarówno na poziomie poetyki i wersyfikacji, jak i metaforyzacji - utwór ów jest najbliższy (ogólnie rzecz ujmując) tradycji wiersza polskiego, w którym dominują zwłaszcza nuty romantyczne i po trosze modernistyczne. $Z$ jednej strony kontekst, swoiste lekturowe echo, tworzą improwizacja Konradowska z Mickiewiczowskich Dziadów i wynurzenia Kordiana na Mont Blanc w utworze Juliusza Słowackiego, wybrzmiewają też imaginacje modernistów (vide - Tadeusz Miciński), a z drugiej strony pojawia się jakaś lubelska, wschodnia, sentymentalna dykcja, wyrażana swoistą melicznością, refrenicznością czy nadrealizmem międzywojennych utworów Józefa Czechowicza i drugiej awangardy. Z pewnością kontekstów literackich dla Podróży znaleźlibyśmy znacznie więcej.

Cóż jednak opowieść peregrynacyjna w Podróży mówi o lirycznym bohaterze, zakładając, że strategia liryki bezpośredniej pozwala nam na ściślejsze związanie bohatera lirycznego $\mathrm{z}$ autorem niż w wypadku innych strategii charakteryzujących mowę wiązaną? Zakładam zatem, że „autor wirtualny (liryczne ja)" i „rzeczywisty" spotkają się w rzeczonym utworze w punkcie interpretacyjnej dominanty, wzmacniając tym samym intencjonalne przesłanie wiersza. Jakie jest więc jego (lirycznego ,ja”) wewnętrzne uposażenie? Wiemy, że marzy, i w poetyckim sensie projektuje niezwykłą, kosmiczną, napowietrzną podróż (konsekwentne używanie czasu przyszłego). Jest to niejako uwewnętrzniona podróż podmiotu świadomości i zarazem ducha, dla którego materia istnieje o tyle, o ile jest dla owej podróży miąższem, jest więc obiektem oglą$\mathrm{du}$,ja", oglądu owych zwyczajno-niezwyczajnych fenomenów wypatrzonej, wymarzonej, wysublimowanej rzeczywistości. Podróż zatem jako znak radykalnej wolności symbolizowanej w utworze Chrostowskiej przez ptaka-duszę (wskazuje nań metafora lotu gdzieś między „sypnięciem się w oczy gwiazdami, a szczytami gór" - lotu między niebem a ziemia), wolności, która nie tylko odnosi się do sfery sensualnego doświadczenia odległości, ale także stanowi przykład wolności radykalnej - chciałoby się rzec, absolutnej i zarazem paradoksalnej. Ów paradoks uchwytny jest w porzuceniu tego wszystkiego, co wynosimy jako ludzie z codziennego doświadczenia zmysłowego, im dalej bowiem znajduje się poetycki „ptak-dusza” Chrostowskiej od mijanych

2 Moja konstatacja ma charakter „myślowej próby”, trudno bowiem w ogóle mówić o znajomości wśród literaturoznawców poezji Grażyny Chrostowskiej. Zdecydował o tym brak publikacji (poza nielicznymi, rozproszonymi wierszami pomieszczonymi w tematycznej antologii wydanej przez muzeum w Oświęcimiu: Aby świat się dowiedziat... Nielegalne dokumenty z obozu $w$ Ravensbrück, red. K. Oleksy, I. Polska, Oświęcim 1980). Dopiero ostatnio Chrostowska doczekała się osobnego (bardzo kunsztownego edytorsko) wydania w 75. rocznicę śmierci. Por. przypis 1. 
„obiektów” - słyszy tym więcej („w srebrnej dali - szumi bór”), im wyżej wznosi się ponad horyzont - zuchwalej zagląda w głąb wód, przenika ciemności. Na dnie owych wód wypatruje tego, co stanowi puentę podróży, jej cel ostateczny - „niemy grób”, dramatyczne świadectwo życia, które w istocie przynależy już do przeszłości, jest po „tej” stronie jej kruchym znakiem.

W tym miejscu - jak sądzę - otwierają się drzwi do rozmaitych koncepcji interpretacyjnych wiersza. Zwrócę uwagę na jedną, dla mnie najbardziej widoczną (właściwie narzucającą się mimowolnie) i najbardziej związaną z kontekstem egzystencjalnym, z istotą ludzkiej natury. Optyka negatywna, chciałoby się rzec, przyjmując takie redukcjonistyczne nastawienie, prowadzi do następującego wniosku: raczej nic po nas ludziach nie zostanie w tej otchłani natury pożerających żywiołów, ale i natury monumentalnej, niewzruszonej, zimnej..., a jeśli - to paradoksalnie - na piaskach (a one są zawsze lotne, niepewne) odciśnie swój ślad „grób niemy”, „bezimienny” - zatem ślad przemijającej obecności i obecności niejako odpersonalizowanej. Jakiejś.

Perspektywa pozytywna: jakąż niezwykłą wolą ducha, imaginacji, sublimacji, wiary trwające istnienie, jeśli zechce, udźwignie w wieczność to, co zostanie w tym metafizycznym wysiłku dojrzane. Moje istnienie - zdaje się mówić poetka - zależy od radykalnej zmiany perspektywy, od odmiennego (innego) stanu skupienia, od jakiejś transcendentalnej autoidentyfikacji.

Rozważania, w których centrum stoi kategoria poetyckiego kreacjonizmu Podróży, skłaniają do uznania estetycznej normy wiersza i zdają się wskazywać na jego niezależne istnienie, niezależne w takim sensie, w jakim mówimy o tym, co ponadindywidualne, ale nie bezimienne. Czy jednak ów utwór spośród wielu z łańcucha tradycji obroni się i pozostanie w „długiej pamięci” jedynie przez samą, nawet najwnikliwszą interpretację? Czy tradycja, konwencja, słowo mają wystarczającą siłę, by zapis był wiarygodny poetycko? Czy utwór Chrostowskiej zostanie zauważony i wyodrębniony w historii polskiego wiersza jako udany kazus, przykład interesującej dykcji? $\mathrm{Na}$ to pytanie nie mam odpowiedzi.

Przykład inny. Tym razem autorką jest Zofia Romanowiczowa.

\section{Chwila trwogi}

Nie, to się stać nie może,

Ach uciec, uciec, uciec -

Po wyślizganym murze

I po kolczastym drucie.

Nie, to się stać nie może -

Ach ukryć się, ach schować!

Wygrzebać z ziemi jamę,

W szparach się skryć jak owad - 
Rozstąpcie mi się ściany!

Otwórzcie się zawiasy!

Niech mnie zakryją wody,

Niech mnie zaszumią lasy!

Nie wiem, gdzie ukryć głowę,

Nie wiem, gdzie schować ręce -

Kaleczę się o głazy

$\mathrm{W}$ mej nierozumnej męce.

Tłukę się w ciasnej celi

Jak ranny ptak skrzydlaty -

Rozstąpcie mi się mury!

Otwórzcie mi się kraty! ${ }^{3}$

I w tym przypadku jesteśmy winni podobny namysł nad strukturą poetycką tego wiersza. Wprawdzie motywu przewodniego nie stanowi peregrynacja w duchu Chrostowskiej, ale jej wariant: ucieczka „poza” i ucieczka „w głąb”, której towarzyszy pragnienie ukrycia się ze swoim istnieniem, również silna potrzeba wydobycia się poza więzienny mur i kolczasty drut, poza świat, w którym istnienie jest stygmatyzowane i bolesne. Nawet gdy się nic nie wie o autorce Chwili trwogi, ma się poczucie pewnej bliskości doświadczenia, aury duchowej i formacyjnej czy estetycznej wrażliwości, które zbliżają te dwie wypowiedzi poetyckie: Chrostowskiej i Romanowiczowej. W wypadku wiersza tej ostatniej wyraźny jest ryt prometejski, romantyczny, furia, nerwowe rozedrganie, ale - jak u Chrostowskiej - i tu wyczuwa się przez odpowiedniość tonu pierwiastek autentycznego przeżycia, jakąś jego „nieestetyzowaną”, niewysiloną dramaturgię. Ale czy mimo niezaprzeczalnych walorów wiersz ma szansę zatrzymać naszą uwagę na dłużej? I czy odpowiedź na to pytanie powinna przyjść tylko ze świata sztuki? Innymi słowy, czy wiersz Romanowiczowej obroni się bez wiedzy czytelnika o okolicznościach jego powstania i o doświadczeniu życiowym poetki? Jak w przypadku Chrostowskiej - jestem sceptyczna.

\section{Świadectwo}

Jak jednak zmienia się nastawienie do Podróży Chrostowskiej, kiedy do interpretacji wiersza włączymy kontekst antropologiczny, w kolejnym kroku biograficzny autorki? Jaką wagę mają dotychczasowe interpretacyjne ustalenia i rozpoznania wobec kontekstu historycznego? Sprawdźmy to. Grażyna

${ }^{3}$ Aby świat się dowiedziat..., dz. cyt., s. 157. 
Chrostowska urodziła się 21 października 1921 roku w Lublinie, ukończyła tam liceum im. Heleny Czarneckiej, a kiedy wybuchła wojna, za sprawą ojca, który organizował struktury państwa podziemnego na Lubelszczyźnie, zaangażowała się wraz z siostrą w konspirację. Ojciec Michał i dwie córki - Pola i Grażyna - działali w Komendzie Obrońców Polski. Grażyna była nie tylko członkinią organizacji podziemnej, ale i kolporterką pisma „Polska Żyje”. Niemcy zatrzymali ją 8 maja 1941 roku, osadzili w areszcie na Zamku w Lublinie i po ogłoszeniu wyroku śmierci wywieźli do obozu kobiecego w Ravensbrück 12 września tego samego roku. Została rozstrzelana 18 kwietnia 1942 w wieku 21 lat! W obozie przeżyła tylko siedem miesięcy, choć mogła mieć nadzieję, że wyrok nigdy nie zostanie wykonany, a ona sama przetrwa piekło zamkniętej zony, wyobrażała sobie bowiem, że już nic gorszego jej nie spotka po dramatycznym pobycie w lubelskim więzieniu. W posłowiu do wydanego w 2017 roku tomu poezji Chrostowskiej Barbara Oratowska zwróciła uwagę nie tylko na etos patriotyczny rodziny Chrostowskich, sympatyzujących przed wojną z sanacją, ale także na interesujące okoliczności pobytu poetki w lagrze. Jak te okruchy świadectw innych współwięźniarek są ważne dla rekonstrukcji postaci, nie trzeba nikogo przekonywać.

Grażyna Chrostowska w obozie pracowała przy wyrobie ocieplaczy słomianych na żołnierskie buty, nawet po dwanaście godzin dziennie. Mimo trudnych warunków każdą chwilę wykorzystywała na pisanie wierszy. Stanisława Śledziejowska-Osiczko, mieszkająca w tym samym co poetka bloku obozowym i jej najbliższa przyjaciółka, uczyła się wszystkich wierszy Chrostowskiej na pamięć .

(...) została rozstrzelana z siostrą Polą i dwunastoma młodymi współwięźniarkami (wszystkie z transportu lubelskiego) 18 kwietnia 1942 roku. Egzekucję przeprowadzono w Totengangu, za murem obozu. Z relacji Kamilli Janowicz-Sycz, która obserwowała z ukrycia, przez otwarte zamalowane okno łazienki w bloku kuchennym, ostatnie chwile koleżanek, wynika, że dziewczęta szły na egzekucję godnie, jakby w transie. Kamilla uchwyciła spojrzenie Grażynki i Poli. „Wiedziałam, że idą na śmierć i do dzisiaj ten widok mam przed oczami"s.

Teraz więcej już wiemy o autorce Podróży. A jeśli dodamy relację o charakterze behawioralnym, ale dopełnioną empatycznym współodczuwaniem koleżanki-więźniarki, dzielącej z nią identyczny los, Wandy Wojtasik-Półtawskiej, pozwalającą wejrzeć głębiej do duchowego wnętrza poetki, Podróż zyskuje. Przez wiarygodny i potwierdzony w relacji ślad autora zyskuje na autentyczności, sens wiersza tym samym pogłębia się, lepiej bowiem rozumiemy wielki dramat człowieka, którego los pozbawił wolności, a przy tym nie poskąpił wyobraźni

\footnotetext{
${ }^{4}$ B. Oratowska, Postowie [w:] G. Chrostowska, Wiersze, dz. cyt., s. 98.

5 Tamże.
} 
marzącej i woli, postawił przed tragicznie trudnym do przyjęcia faktem bezimienności w śmierci (ów motyw wyrażony we frazie: „na piaskach niemy grób”).

Nie uległa presji otoczenia - wspomina Wojtasik-Półtawska - zresztą my wszystkie, cały polityczny z 21 września 1941 roku z Zamku w Lublinie, mniej lub bardziej świadomie walczyłyśmy zarówno na Zamku, w więzieniu, jak i w lagrze, żeby nie dać się wchłonąć i żeby nie zejść do roli kadłubów, co oznaczało człowieka sprowadzonego do poziomu czystej wegetacji, niejako odmóżdżonego, a taki był cel okupanta wobec nas, Polaków - obóz koncentracyjny miał na celu zniszczenie człowieka i całego narodu... Właśnie poezja była jednym ze sposobów oderwania się od makabrycznej rzeczywistości - myślę, że w pewnym sensie Grażynce przychodziło łatwiej niż nam oderwać się czy wręcz nie zauważyć tego, co się działo dookoła nas. Była jakby trochę nieobecna, wpatrzona w obrazy, o których pisała na zdobytych skrawkach papieru' ${ }^{6}$.

Zachowało się kilka spisanych wspomnień koleżanek o Grażynie Chrostowskiej: Janiny Iwańskiej, Bogumiły Bąbińskiej-Jasiuk, Zofii Górskiej-Romanowiczowej, Wandy Wojtasik-Półtawskiej, Kamilli Janowicz-Sycz, Stanisławy Śledziejowskiej-Osiczko - podaje w Postowiu Barbara Oratowska. Można powiedzieć: przecież to mało. Jak niewiele pozostało po człowieku o tak dużym potencjale twórczym i dysponującym znakomitym kapitałem kulturowym, inteligenckim z ducha młodej Drugiej Rzeczpospolitej. Niewiele, ale za to jak intensywne są wspomnienia o Grażynie i jakże ciepłe:

tyle lat minęło, a mam ją w oczach - wspomina Wanda Półtawska - jakby to było wczoraj, i ten żal, że jej nie dano żyć, nie da się tak całkiem zniwelować - och, nie chodzi o to, żeby robić rozrachunki, kto ile i jakie zbrodnie popełnił, ale niektóre są szczególnie boleśniejsze - widzę białą główkę Grażynki opartą na ręce, wpatrzona w okno pisze wiersz o słoneczniku. Wsłuchana w swoje własne słowa, które snuje z pewną nieśmiałością, a zarazem z przekonaniem, że ze słów można wydobyć prawdziwe piękno. Lubiłyśmy ją wszystkie - i jestem pewna, że wszystkie ją pamiętają czy raczej pamiętały do końca swojego życia. Grażynka powinna zostać w pamięci młodzieży jako symbol pięknej młodości - zaadresowanej do wartości nieprzemijających, do poezji i do Ojczyzny, bo te wartości są zagrożone niepamięcią?

Podróż jest więc zarówno rezultatem kreacji, jak i świadectwa, a także bardzo głębokim i autentycznym śladem autorki. Okoliczności powstania utworu, jego duchowa geneza pozwalają nam uzyskać efekt finalny - heureza kontekstu i hermeneutyka umożliwiają wydobycie głębokiego sensu, który zza słów się wynurza. Ale i bez tej kontekstowej wiedzy wiersz obroni się z pewnością przy zastrzeżeniach, o których mówiłam na wstępie.

\footnotetext{
6 Tamże.

7 Tamże, s. 99.
} 
Popatrzmy na te zależności z drugiej strony, to jest wychodząc od okoliczności, w jakich rodzi się myśl twórcza. Proponuję tym razem tę samą analizę, choć w centrum powinna się teraz znaleźć kategoria świadectwa. Najpierw więc wykorzystujemy naszą wiedzę o biografii autora, a w praktyce właściwie już czytamy „uprzedzająco", o ile autor jest nam dobrze znany. Interpretacja staje się w tych okolicznościach fuzją czy też katalizą wiedzy kontekstowej, którą aplikujemy do sensu już na najniższym poziomie analizy. Wydaje się też, że w takim postępowaniu mamy większą szansę, by dostrzec okruchy i drobiazgi tworzące konstelacyjny krąg interpretacyjny, wznosić budowlę na kolejne piętra rozumienia - aż po dominantę.

Raz jeszcze Grażyna Chrostowska, tym razem utwór Śmierć i pobrzmiewająca w nim melodia Norwidowskiego Fatum, ale rzecz jasna - nie tylko, ten krótki utwór ma bowiem również ciekawą i zarazem intrygującą, nieoczywistą konstrukcję dialogową:

Śmierć ma oczy jasne, zawsze jest daleka,

Kędyś tam przyczajona widzi mnie i czeka.

Nic o niej nie wiem jeszcze -

Powiedz - miała Szopenowskie ręce,

Była dla Ciebie gwiazdą przewodnią przez światy nieznane?

I czemu tak wcześnie, zbyt wcześnie przybyła - kochanie?

A na 5 dni przed egzekucją napisała:

To tylko zbyt wcześnie

Dotknęło mnie cierpienie,

Że cała się spaliłam

Na martwy, jasny popiół

I pozostało tylko wytrwałe milczenie.

Co prawdę odsłania.

Wszak wciąż stoję w ogniu... [R $\mathrm{R}^{8} 13$ IV 1942]

Czy nie przemawiają do nas bardziej te dwa wiersze, jeśli wiemy, że namysł nad tajemnicą śmierci nie był li tylko poetycką licencją Chrostowskiej, ale trwożną codziennością doświadczenia? Wszak przebywała w Ravensbrück z wyrokiem śmierci, który wisiał jednak nad nią jak miecz Damoklesa.

Podobna sytuacja występuje w wypadku utworów Romanowiczowej. W cyklu Chwile ostatnie znajdujemy tekst Chwila zamętu, jego fragment przywołany poniżej dopełnia wypowiedź o tym, co ostateczne, na progu, na granicy Nieznanego... I chociaż wiersz ów nie należy do wyrafinowanych artystycznie, to znając biografię autorki, trudno mu odmówić powagi:

\footnotetext{
${ }^{8}$ Ravensbrück.
} 
Jak trudno to zrozumieć... Więc to ma być koniec?!

Opadły mi myśli i ręce...

Stoję i czuję serce, jak rwie się i płonie

Obłąkane, szalone, zwierzęce.

Jakiś szum mnie zagarnia - myśli giną w szumie,

Jakiś prąd mnie wbrew woli zabiera -

Jak to - więc to już koniec? Ja umrzeć nie umiem!

Ja nie umiem, ja nie chcę umierać! ${ }^{?}$

Posłużyłam się w swojej wypowiedzi zaledwie kilkoma wierszami obu autorek, których kres życia istotnie się różni. Poezja więzienna i lagrowa Zofii Romanowiczowej była tylko etapem w biografii twórczej, mimo że jak się zdaje - etapem najważniejszym. Emigrację, choć też trudną, pisarka przyjęła z ulgą przecież. Miała również szansę wielokrotnie wypowiedzieć się na temat swoich lagrowych przeżyć, powracać pamięcią po latach do tych doznań i doświadczeń, obmyślać język, szlifować narrację, by oddać istotę tego, co skrajnie trudne do wypowiedzenia, wręcz niemożliwe ${ }^{10}$. Biografia Romanowiczowej u początków dojrzałej drogi bliska była doświadczeniu Chrostowskiej, obie pochodziły spoza Warszawy, nie odbiegały od siebie statusem społecznym; ich rodziny - obie inteligenckie (Romanowiczowa to córka legionisty, urzędnika, Zygmunta Górskiego, i Marianny ze Stolińskich). Ukończyła liceum w Radomiu i już w okresie szkolnym była aktywna literacko podobnie jak Chrostowska. W czasie okupacji pracowała na rzecz polskiego państwa podziemnego, była łączniczką Związku Walki Zbrojnej w Radomiu i podobnie jak Chrostowska - została aresztowana przez gestapo, uwięziona i ostatecznie przewieziono ją do obozu koncentracyjnego w Ravensbrück, później - do Neu-Rohlau. Po wyjściu z obozu, który wyzwolili Amerykanie, wyjechała do Włoch, gdzie w liceum 2. Korpusu Armii Polskiej mogła nie tylko kontynuować naukę, ale i publikować w wydawanych na wychodźstwie polskich pismach: „Orzeł Biały”, „Ochotniczka”, „Kresowym Szlakiem”. Po zdaniu matury i otrzymaniu stypendium Polskiej Misji Katolickiej w Paryżu rozpoczęła Romanowiczowa kurs filologii romańskiej na Sorbonie, niebawem też poślubiła Kazimierza Romanowicza, księgarza i wydawcę, z którym przez pół wieku współtworzyła jeden z ważnych ośrodków emigracji niepodległościowej - wydawnictwo Libella oraz Galerię Lambert na paryskiej Wyspie św. Ludwika. Po wojnie współpracowała między innymi z londyńskimi „Wiadomościami” i paryską „Kulturą”. W 1961 roku ukazała się antologia wierszy

9 Aby świat się dowiedziat..., dz. cyt., s. 155.

${ }^{10}$ Więcej na temat twórczości Romanowiczowej między innymi: A. Jamrozek-Sowa, $\dot{Z} y$ cie powtórzone. O pisarstwie Zofii Romanowiczowej, Rzeszów 2008; A. Morawiec, Zofia Romanowiczowa. Pisarka nie tylko emigracyjna, Łódź 2016. 
dokumentujących traumę okresu pobytu w Ravensbrück: Ravensbrück. Wiersze obozowe, w której znalazły się utwory Romanowiczowej. Miała więc Romanowiczowa życie bogate i długie, obfite w różne zdarzenia, dopełnione radością posiadania córki i muzy zarazem - Barbary.

Grażynie Chrostowskiej - los poskąpił długiego życia, jakie miała Romanowiczowa. I ten fakt być może każe mi z młodą kobietą-poetką przebywać dłużej, współodczuwać z nią, wzruszać się. To jej świat - świat na zawsze młodej osoby - przemawia do mnie siłą owej nieodwołalności i wiecznej aktualności tragicznego momentu, w jakim zastygła. Wszystkie wiersze Chrostowskiej ocalałe w niezwykłych okolicznościach, wzmacniają empatię i waloryzują to całe jej niepodzielne dzieło: biografii i twórczości. Gdy uwzględni się biografię autorki To tylko zbyt wcześnie..., wtedy zauważalne potknięcia techniczne, niezborności wierszy, powtórzenia, które mają charakter poszukiwania właściwej aplikacji sensów, zbytnio nie drażnią, jesteśmy nawet skłonni uznać je za konieczne. Chrostowska mogłaby przecież swoje wiersze zredagować na nowo, procesualnie udoskonalać, rozpisać myśli na inwariantywne propozycje. Niestety, wiemy, że nie było to możliwe. Zostawiła po sobie pospieszne impresje, ale za to wyraziste, zindywidualizowane (to przecież historia Kolumbów, tyle że regionalna). W dodatku niewiele jej autografów zachowało się jako świadectwa źródłowe, część wierszy przetrwała dzięki zapisom z pamięci koleżanek-więźniarek, które, siedząc na pryczach, słuchały w owym koszmarnym czasie utworów i przez magiczną chwilę marzycielskiej wędrówki poza mury obozu czuły się dokładnie tak, jak liryczna bohaterka Podróży. To skądinąd piękny motyw w polskiej kulturze: edukacja tylko w XX wieku była realizowana przygodnie, acz skutecznie w miejscach skupienia społeczności Polaków: w obozach niemieckich i łagrach sowieckich. Tam rozwijało się gawędziarstwo, toczyły się dyskusje o kulturze, sztuce i polityce, tam uprawiano sztukę (dwa znane przykłady: praca edukacyjna Karoliny Lanckorońskiej osadzonej w lagrze i Józefa Czapskiego w Griazowcu w ZSRR).

Oczywiście, pozostałe wiersze Chrostowskiej i Romanowiczowej, o których nie było mowy w niniejszym sygnalnym szkicu, jak również innych więźniarek-poetek mają wyraźną sygnaturę autobiograficzną, rekonstruują zdarzenia obozowe, zdają się na przykład być wiernym zapisem rytmu dnia i reżimu panującego w zamkniętym świecie lagrów, dotykają też sfery intymistycznej, eksplorują poprzez język sferę doświadczeń cielesnych, stając się tym samym mapą emocji i miejsc w topografii obozu, które je wywołują. Są też ucieczką w przeszłość do krajobrazu, architektury i ludzi, do świata z czasu wolności. W takich okolicznościach pamięć i wyobraźnia sublimująca tworzą szczególną więź, owocującą narracją, przesyconą głębokim wzruszeniem, faktem rozpoznanej i uwewnętrznionej utraty. Zdarzają się w poezji lagrowej utwory patriotyczne, nawet „bojowe”, harde, wyrażające wierność wartościom wspólnotowym, narodowym, państwowym, najczęściej jednak spotykamy mnogość wierszy-modlitw, wierszy jak paciorki nanizanych na różaniec, snutych 
na kanwie roku liturgicznego, wokół Ogrójca, cierpienia Boga i człowieka. Są one estetyzowaną próbą przeglądania się człowieka w cierpiącym Bogu, zbliżenia się do tego, co Nieznane, nieodpoznane, do granicy wszystkiego tego, co z perspektywy egzystencji przekracza ludzką kondycję.

Poezja obozowa (podobnie jak proza czy zapisy wprost dokumentalne) stanowi znakomity materiał do namysłu nad różnymi warstwami świadectwa, dokumentu artystycznego, gdzie ślad autora jest wyrazisty, jeśli nawet wydaje się mocno ukryty pod powierzchnią retoryki. Podpowiedź teoretyczną dają nam między innymi prace Małgorzaty Czermińskiej ${ }^{11}$, ponieważ materiał artystyczny czy quasi-artystyczny dla takiej postawy badawczej znajduje się w wielu archiwach prywatnych, muzealnych, niewielka zaś ich część została ogłoszona ${ }^{12}$. Analiza splotu czynników, takich jak spotkanie tradycji literackiej (i religijnej) z indywidualnym traumatycznym doświadczeniem piszącego - dającego świadectwo, wyposaża nas w wiedzę, która w inny sposób nie byłaby dostępna, w myśl Gadamerowskiej zasady, że estetyka służy hermeneutyce $^{13}$. A jednocześnie to właśnie doświadczenie graniczne powoduje, że w rezultacie szczególnego napięcia uczuć i umysłu powstają utwory najwyższej próby, można rzec - skończone, autentyczne dzięki odczuwanej przez czytelnika odpowiedniości tonu, jakiejś szczerości wyrazu. Napięcie estetyczne bowiem może jeszcze wzrastać, gdy czytelnik zyskuje wiedzę o okolicznościach towarzyszących powstaniu utworu. $\mathrm{Z}$ taką sytuacją mamy do czynienia - jak mi się zdaje - w odniesieniu do wierszy, o których była tu mowa. Legenda autorki (zwłaszcza Chrostowskiej) wzmacnia przekaz poetycki, waloryzuje go, czyni go wyjątkowym i sprawia, że staje się zachętą do dalszej, pogłębionej lektury, która wyprowadza nas z naszego wygodnego świata w przestrzeń nieznaną i proponuje peregrynację przez najważniejsze węzły człowieczego życia. Czekamy po dziś dzień na obszerną pracę analizującą twórczość poetycką czy rymowaną lagrową i łagrową (o prozie wiemy znacznie więcej), gdyż ona właśnie była najbliżej źródła przeżycia, powstawała na skrawkach papieru wyzyskanego z kopert, z opakowań, pisana jak list atramentem z moczu, jeśli wędrowała poza obóz, ołówkiem - gdy zostawała wewnątrz.

${ }_{11}$ Zob. M. Czermińska, Autor-podmiot-osoba. Fikcjonalność i niefikcjonalność [w:] Polonistyka w przebudowie. Literaturoznawstwo - wiedza o jezyku - wiedza o kulturze-edukacja, red. M. Czermińska, S. Gajda i in., t. 1, Kraków 2005; taż, Autobiograficzny trójkąt. Świadectwo, wyzwanie i wyznanie, Kraków 2000. Zob. też R. Nycz, Osoba w nowoczesnej literaturze. Ślady obecności [w:] tegoż, Literatura jako trop rzeczywistości, Kraków 2001.

12 Powodów, dla których wierszy nie opublikowano, jest wiele, chodzi m.in. o ich poziom artystyczny i anonimowość. Kłopotów nastręcza też potencjalnym wydawcom ustalenie ostatecznego wariantu konkretnego utworu, który przez wielokrotne przepisywanie w obozie (nie tylko przez autora, ale i uczących się go na pamięć słuchaczy i świadków) i później po latach (kiedy słuchaczowi udało się przeżyć lager) zmienia czasem swój ostateczny sens.

${ }^{13}$ H.G. Gadamer, Estetyka i hermeneutyka [w:] tegoż, Rozum, stowo, dzieje, wyb., oprac., wstęp K. Michalski, tłum. M. Łukasiewicz, K. Michalski, Warszawa 1979. 
Jeśli chodzi o poetycką twórczość łagrową, świadectw tej aktywności publikowano jak dotąd niewiele, wyjątek stanowi tłumaczenie Zofii Bohdanowiczowej, o tyle ciekawe, że autorkami są kobiety nie-Polki. Maryjo, ratuj nas (Marija, gelbeki mus) - to modlitewnik powstały w sowieckim łagrze, ułożony przez cztery Litwinki zesłane do obozu pracy w 1944 roku. Modlitewnik jest rezultatem przeżytych cierpień, doznanych upokorzeń, doświadczenia głodu, tortur i poniżenia, jest zatem niezwykle osobistym i autentycznym (choć wyraźnie skonwencjonalizowanym) zapisem rozmowy udręczonego człowieka z Bogiem. Z Syberii modlitewnik trafia na Litwę i stamtąd przewieziony zostaje do USA. Szybko zostaje wydany w języku litewskim i angielskim (1959) oraz dzięki Bohdanowiczowej - w języku polskim. W 1966 roku ukazuje się nakładem Towarzystwa Polsko-Litewskiego im. A. Mickiewicza w Wielkiej Brytanii, ponownie w Polsce w roku 1994, także wydany przez siostrzane Towarzystwo im. A. Mickiewicza (w Oddziale Białostockim) ${ }^{14}$. Podobnych świadectw potencjalnie może być więcej (nadzieja w niedawno powstałym Muzeum Sybiru w Białymstoku, do którego mają szansę trafiać zbiory prywatne po łagiernikach). Wiadomo, iż takich obozowych relacji i utworów o estetycznej proweniencji zgromadzono całkiem sporo, można więc mieć nadzieję, że będą stanowić dopełnienie wydanych na emigracji i po 1989 roku w Polsce (zwłaszcza w ostatnich kilku latach) świadectw o charakterze dokumentalnym czy literackim ${ }^{15}$.

Swoistą kodą krytycznego rzutowania na twórczość lagrową i łagrową, na jej rys dokumentalny i antropologiczny, może być dalsza jej lektura poprowadzona wokół utworów powstałych na kanwie pamięci potomnych. Ich autorami zostają często członkowie rodzin, przenoszący w żywej pamięci historię dramatu obozowego swoich przodków. Oni właśnie - korzystając z komfortu cyzelowania słów, powolnej i procesualnej kreacji - mają szansę stworzyć (i tak się nierzadko dzieje) lirykę wysokiej próby. Gwarancją jej znaczenia i zarazem artystycznej jakości staje się silna więź emocjonalna ze światem ojców, z ich świadectwem, niesionym w przyszłość przez zapis relacji, przez opowieść, mit jednostkowy, rodzinny, wspólnotowy. Tu namysł nad doświadczeniem pokoleń stanowi punkt wyjścia do snucia refleksji nad tajemnicą ludzkiej natury, a rozważać ją mogą zarówno ci, którzy piekło obozu przeżyli (jak Zofia Romanowiczowa), jak i ci, którym takie traumatyczne świadectwo ludzkiego losu nie jest obojętne.

Estetyka - idąc tropem Hansa-Georga Gadamera - daje szansę, by „graniczne" świadectwo Chrostowskiej i innych ocalałych autorów okazało się ważne i dzisiaj, by służyło wzmocnieniu samej pamięci o wydarzeniach

${ }_{14}$ Zob. Z. Bohdanowiczowa, Rapsody litewskie, Maryjo, ratuj nas (przektad z litewskiego), wydała i wstępem opatrzyła V. Wejs-Milewska, Białystok 1994.

15 Zob. Polskie wiersze obozowe i więzienne 1939-1945 $w$ archiwum Aleksandra Kulisiewicza, oprac., przedm. K. Strzelewicz, Kraków 1983; Na mojej ziemi byt Oświęcim... Oświęcim w poezji wspótczesnej, wyb., oprac. A. Zych, cz. 1, Oświęcim 1987, cz. 2, Oświęcim 1993. 
(o faktach) i aby pozostało wciąż żywym źródłem niezgody, źródłem zawsze świeżego zdziwienia, które rodzi zadane z głębi tragicznego nierozumienia dziejów pytanie: jak to było możliwe? Póki pytanie to stawiamy, póty mamy szansę na ocalenie.

Chrostowska - poetka i człowiek ze świata Ravensbrück - mówi do nas w wiecznym teraz, natężmy więc słuch, by zmieniać swoje życie...

\section{Bibliografia}

Aby świat się dowiedziat... Nielegalne dokumenty z obozu w Ravensbruck, red. K. Oleksy, I. Polska, Oświęcim 1980.

Bohdanowiczowa Z., Rapsody litewskie, Maryjo, ratuj nas (przektad z litewskiego), wydała i wstępem opatrzyła V. Wejs-Milewska, Białystok 1994.

Chrostowska G., Wiersze, oprac. B. Oratowska, J. Cymerman, Lublin 2017.

Czermińska M., Autobiograficzny trójkąt. Świadectwo, wyzwanie i wyznanie, Kraków 2000.

Czermińska M., Autor-podmiot-osoba. Fikcjonalność i niefikcjonalność [w:] Polonistyka w przebudowie. Literaturoznawstwo - wiedza o jezyku - wiedza o kulturze-edukacja, red. M. Czermińska, S. Gajda i in., t. 1, Kraków 2005.

Gadamer H.-G., Estetyka i hermeneutyka [w:] tegoż, Rozum, stowo, dzieje, wyb., oprac., wstęp K. Michalski, tłum. M. Łukasiewicz, K. Michalski, Warszawa 1979.

Jamrozek-Sowa A., Życie powtórzone. O pisarstwie Zofii Romanowiczowej, Rzeszów 2008.

Morawiec A., Zofia Romanowiczowa. Pisarka nie tylko emigracyjna, Łódź 2016.

Na mojej ziemi byt Oświęcim... Oświęcim w poezji wspótczesnej, wyb., oprac. A. Zych, cz. 1, Oświęcim 1987, cz. 2, Oświęcim 1993.

Nycz R., Osoba w nowoczesnej literaturze. Ślady obecności [w:] tegoż, Literatura jako trop nowoczesności, Kraków 2001.

Polskie wiersze obozowe i więzienne 1939-1945 w archiwum Aleksandra Kulisiewi$c z a$, oprac., przedm. K. Strzelewicz, Kraków 1983. 